Potensi Situs Gua Hunian Prasejarah di Kawasan Karst

Pegunungan Meratus, Kalimantan Selatan 1-11

\title{
POTENSI SITUS GUA HUNIAN PRASEJARAH DI KAWASAN KARST PEGUNUNGAN MERATUS, KALIMANTAN SELATAN
}

\author{
Bambang Sugiyanto* \\ BalaiArkeologi Banjarmasin, Jalan Gotong Royong II, RT 03/06, Banjarbaru 70711, Kalimantan Selatan; \\ Telepon (0511) 4781716; Facsimile (0511) 4781716
}

Artikel masuk pada 12 Desember 2012

Artikel selesai disunting pada 26 Maret 2013

\begin{abstract}
Abstrak. Situs gua prasejarah yang telah memberikan informasi yang komprehensif mengenai pemukiman adalah Gua Babi dan Gua Tengkorak yang ditemukan di zona utara lingkungan karst Pegunungan Meratus. Kawasan karst ini ditemukan memanjang dari zona utara sampai dengan selatan. Setiap zona menunjukkan kronologi okupasi yang berbeda-beda dari masa Mesolitik sampai Neolitik. Tulisan ini membahas faktor-faktor yang menjadi dasar pertimbangan manusia prasejarah dalam mengokupasi kawasan karst Pegunungan Meratus. Studi ini dilakukan dengan menggunakan metode deskriptif dan penalaran induktif. Hasil studi menunjukkan bahwa okupasi kawasan Pegunungan Meratus telah terjadi sekitar 6.000 tahun lalu oleh kelompok manusia yang memiliki mata pencaharian berburu dan mengumpulkan makanan. Kegiatan okupasi di kawasan karst tersebut dilandasi oleh pertimbangan potensi air bersih dan sumber daya alimentasi yang potensial yang mendukung eksistensi keseharian manusia.
\end{abstract}

Kata kunci: karst, gua hunian, alat-alat prasejarah, orohydrografi, zoogeografi, daerah aliran sungai, alimentasi

\begin{abstract}
PREHISTORIC CAVE DWELLING IN THE KARST REGION OF MERATUS MOUNTAIN, SOUTH KALIMANTAN. Prehistoric caves which have provided comprehensive information on settlement are Gua Babi and Gua Tengkorak which were found in the northern zone of the karst region of Meratus Mountain. The karst region was found extending from the north to the southern zone. Each zone shows different chronology of occupation from the Mesolithic to the Neolithic period. This paper discusses the factors which determine the consideration of prehistoric human to occupy the karst region of Meratus Mountain. The study was conducted by using descriptive and inductive reasoning. The result shows that the occupation of Meratus Mountains had occurred approximately 6,000 years ago by a group of people who lived from hunting and food gathering. The occupational activity in such karst region occurred due to the consideration of potential water supply and food resources to support human's day-to-day existence.
\end{abstract}

Keywords: karst, dwelling cave, prehistoric tools, orohydrography, zoogeography, river basin, alimentation

* Penulis adalah Peneliti Madya pada Balai Arkeologi Banjarmasin, email: iyan_balar_bjb@yahoo.com 


\section{A. Pendahuluan}

\section{Latar Belakang}

Perkembangan dan dinamika budaya prasejarah yang pernah ada di wilayah Kalimantan Selatan menunjukkan beberapa situs bekas lokasi hunian manusia prasejarah dalam gua atau ceruk. Budaya prasejarah itu antara lain: temuan kapak bahu di daerah Sungai Semayap (Kabupaten Kotabaru), temuan kapak perimbas-penetak di dasar Sungai Riam Kanan, yang sekarang sudah menjadi waduk pembangkit listrik, dan temuan gua hunian di Desa Randu, Kabupaten Tabalong, yaitu Gua Babi dan Gua Tengkorak. Situs-situs bekas hunian ini membuktikan kehadiran sekelompok manusia prasejarah yang dulu pernah tinggal dalam gua dan ceruk yang ada pada kawasan karst. Kelompok manusia ini mengembangkan budaya dan teknologi batu yang cukup maju sebagai jalan untuk dapat bertahan hidup sesuai dengan lingkungan hidup yang ada. Tentunya situssitus hunian itu tidak hanya ada di wilayah Kabupaten Tabalong saja, kemungkinan besar masih ada gua dan ceruk lainnya di wilayah Provinsi Kalimantan Selatan.

Budaya prasejarah yang berada di Situs Gua Babi dan Gua Tengkorak merupakan salah satu bagian dari kelompok budaya yang pernah berkembang pesat di kawasan karst yang ada di sekitar Pegunungan Meratus. Kawasan karst itu antara lain berada di wilayah Kabupaten Tabalong, Hulu Sungai Tengah, Hulu Sungai Selatan, Tapin, dan Banjar yang terletak di bagian barat Pegunungan Meratus. Sementara kawasan karst yang berada di bagian timur Pegunungan Meratus antara lain tersebar di wilayah Kabupaten Kotabaru, Hulu Sungai Selatan, Tanah Bumbu, dan Banjar.

Sejak tahun 2006, wilayah Kecamatan Mantewe di Kabupaten Tanah Bumbu menjadi salah satu daerah penelitian arkeologi prasejarah yang dilakukan oleh Balai Arkeologi Banjarmasin. Hasil penelitian survei memperlihatkan bahwa Kecamatan Mantewe mempunyai sumberdaya kawasan karst yang cukup luas. Kawasan karst ini terhampar secara acak pada beberapa desa yang ada, seperti Desa Mantewe, Desa Bulurejo, Desa Dukuhrejo, Desa Rejosari, dan Desa Sukadamai. Kawasan karst tersebut ada yang berupa deretan perbukitan karst yang panjang dan ada juga yang berupa satu gugus bukit atau gunung karst sendiri. Deretan perbukitan karst di wilayah Desa Mantewe paling tidak mempunyai dua buah situs gua potensial, yaitu Gua Sugung dan Gua Landung. Sementara yang berupa gugusan bukit tersendiri seperti Bukit Batu Tanjak di Desa Bulurejo, mempunyai satu gua dengan dua buah pintu masuk. Gua ini disebut dengan Gua Batu Tanjak atau Gua Payung. Sementara di Desa Dukuhrejo, juga terdapat satu gugus karst yang mempunyai banyak gua dan ceruk layak huni. Salah satu ceruk yang sudah diteliti dan masih berlanjut sampai sekarang adalah Liang Bangkai, yang merupakan sebuah ceruk payung yang pernah dimanfaatkan manusia prasejarah ribuan tahun lalu.

Gua Sugung, berdasarkan hasil test pit yang dilakukan tahun 2006 memperlihatkan indikasi hunian manusia yang cukup intensif di bagian teras gua. Indikasi hunian manusia tergambarkan pada banyaknya sisa makanan berupa cangkang siput yang ditemukan serta sisa peralatan mereka pada masanya. Sementara Gua Payung (Batu Tanjak) yang ada di Desa Bulurejo, sebenarnya merupakan situs gua hunian yang sangat potensial dan penting bagi penelitian sejarah kebudayaan di Kalimantan Selatan. Sayangnya, data 
tersebut sudah hilang tercerabut dari dalam tanah, akibat dari adanya penambangan guano (kotoran kelelawar) yang banyak dilakukan untuk usaha pertanian atau perkebunan masyarakat. Peninjauan dan penelitian terbaru di Gua Payung yang dilakukan tahun 2012 menunjukkan bahwa gua tersebut secara umum sudah rusak berat, dan data-kehidupan sejarah manusia yang pernah tinggal di dalamnya juga mengalami kerusakan yang sama besarnya. Maraknya kegiatan perkebunan kelapa sawit diduga merupakan faktor pemicu utama adanya upaya pemanfaatan guano oleh masyarakat di sekitar situs.

\section{Permasalahan}

Masing-masing kawasan karst di atas mempunyai bukti kehidupan manusia prasejarah pada masa lalu. Kawasan karst yang ada di bagian timur tenggara mempunyai temuan kapak batu Paleolitik yang berasal dari Sungai Semayap dan Sungai Riam Kanan. Sementara ciri kehidupan Mesolitik-Neolitik antara lain ditemukan di Gua Sugung, Gua Payung, dan Liang Bangkai. Budaya prasejarah di kawasan karst di bagian barat utara Pegunungan Meratus antara lain terwakili oleh temuan Gua Babi dan Gua Tengkorak. Sisa penguburan secara terlipat yang ada di Gua Tengkorak merupakan bukti kuat tentang manusia pendukung budaya prasejarah yang pernah berkembang di situs itu. Apa yang mendasari pilihan manusia prasejarah menempati kawasan karst di sekitar Pegunungan Meratus ini?

\section{B. Gua-gua Prasejarah di Kalimantan}

Sejarah penghunian Kalimantan merupakan tahapan awal kehidupan dan kebudayaan prasejarah di pulau besar ini.
Penghunian ini sangat dipengaruhi oleh proses glasiasi yang terjadi beberapa kali. Proses glasiasi yang terjadi di daerah Sedang Utara selama Kala Plestosen ini telah menyebabkan adanya variasi perubahan permukaan air laut di seluruh dunia, termasuk kepulauan Indonesia yang terletak di daerah katulistiwa. Ketika sebagian besar air laut membeku menjadi es karena turunnya suhu yang hebat, terjadilah "susut" laut (regresi) dengan penurunan muka laut yang kadang mencapai 100 meter (Semah 1996). Menurut Molengraaff dan Weber (1921), regresi air laut selama periode glasial Wûrm mencapai 72 meter, sementara De Terra (1943) menghitung penurunan sekitar 120 meter pada periode glasial Mindel, susut laut paling intensif selama Kala Plestosen. Pengaruh glasiasi pada Laut Jawa dan Laut Cina Selatan yang hanya sedalam sekitar 40 meter, diikuti oleh gerakan eustatik lempeng bumi menyebabkan terjadinya pengangkatan dataran Sunda secara parsial, telah membentuk jembatan-jembatan darat beberapa kali, sehingga dapat menghubungkan Kalimantan dengan pulau Jawa, Sumatera, dan daratan Asia. Jembatan darat ini telah memungkinkan terjadinya migrasi mamalia dari daratan Asia Tenggara ke Kalimantan dan pulau-pulau lainnya. Terakhir kali, berpisahnya Kalimantan dengan daratan Asia Tenggara terjadi pada saat genang laut (transgresi) pada Kala Holosen, sekitar 11.000 tahun silam .

Situasi pisah-sambungnya pulau Kalimantan, Jawa, dan Sumatera dalam konteks Dataran Sunda merupakan fenomena alam yang sangat berpengaruh bagi kehidupan masa lalu di daerah ini. Jembatan darat ini telah mendasari beberapa ahli untuk menggambarkan migrasi mamalia selama 
Kala Plestosen (Koniegswald 1934; 1935; de Terra 1943; Heekeren 1972). Jalur migrasi pertama adalah Asia Tenggara daratan ke Jawa, terus ke timur ke Nusa Tenggara. Jalur pertama ini diikuti dengan jalur kedua dari Cina Selatan, Taiwan, Filipina, Kalimantan, dan Sulawesi dengan melalui jembatan darat Sangihe. Pendapat ini telah menyebabkan munculnya hipotesis bahwa Kalimantan juga mempunyai peran yang sama dengan pulaupulau lain di Indonesia bagian barat, dalam menampung berbagai aktivitas migrasi Kala Plestosen, meliputi migrasi binatang dan juga manusia, sehingga ada kemungkinan besar ditemukan jejak-jejak masa lalu manusia prasejarah (Widianto 1997).

Menurut Harry Widianto (1997, 1-2), lokasi yang sebaiknya diperhatikan untuk wilayah Kalimantan Selatan adalah bagian tengah yang didominasi oleh Pegunungan Meratus yang membentang pada arah utara-selatan. Bagian selatan dan barat wilayah Kalimantan Selatan didominasi oleh tanah rawa. Jenis tanah rawa ini mempunyai sifat keasaman yang tinggi, sehingga tidak akan mampu untuk mengkonservasi tulang belulang manusia maupun binatang. Konservasi tulang belulang ini akan berlangsung secara baik pada kawasan karst, yang banyak terdapat di sekitar Pegunungan Meratus. Pegunungan kapur atau kawasan karst inilah merupakan tempat yang paling memberikan harapan untuk bisa menemukan situs prasejarah masa lalu. Perhatian akan lebih baik jika diarahkan ke gua atau ceruk yang banyak terdapat pada suatu kawasan karst.

Kawasan karst banyak terdapat di sekitar Pegunungan Meratus, yang merupakan kawasan pegunungan yang membelah Provinsi Kalimantan Selatan yang membentang sepanjang sekitar 600 kilometer persegi dari arah tenggara dan membelok ke arah utara hingga perbatasan Kalimantan Timur. Kawasan karst di Pegunungan Meratus ini tersebar secara acak sedikitnya pada delapan wilayah kabupaten, mulai dari Kabupaten Tabalong di bagian utara, Hulu Sungai Tengah, Balangan, Hulu Sungai Selatan, Tapin, Banjar, Tanah Bumbu, dan Kotabaru. Potensi hunian prasejarah sangat besar pada kawasan karst tersebut.

Dibandingkan dengan pulau-pulau lain, Kalimantan adalah pulau yang jarang ditemukan data arkeologi dari masa prasejarah. Data prasejarah Kalimantan ditemukan pada sebuah gua di belahan utara pulau Kalimantan, yaitu di Serawak, Malaysia. Di Gua Niah, Serawak, ditemukan tulangtulang homo sapiens yang menandai sejarah keberadaan manusia pertama di Kalimantan (Majid vide MacKinnon et. all. 1996, 58). Situs Gua Niah diperkirakan berasal dari kala Plestosen Akhir, ketika manusia sudah mulai menggunakan alat-alat paleolitik (Bellwood 1985 vide MacKinnon et.al. 1996, 55). Alatalat paleolitik yang ditemukan di Gua Niah diperkirakan semasa dengan alat-alat serpih yang ditemukan di Pacitan, Jawa Tengah. Di Gua Niah juga ditemukan lukisan perahu arwah dan peti kubur kayu yang berasosiasi dengan manik-manik, gerabah dan sisa-sisa logam. Hasil analisis radiokarbon $\mathrm{C} 14$ terhadap peti kubur kayu menunjukkan usia antara 460 BCE - 1.000 CE (MacKinnon et.all. 1996, 58).

Di Kalimantan Selatan, penelitian tentang hunian gua dilaksanakan dari tahun 1996 sampai dengan tahun 1999, yaitu di Gua Babi, wilayah Bukit Batu Buli di Kabupaten Tabalong. Gua Babi merupakan bukti keberadaan aktivitas manusia dari sekitar 6000 tahun yang lalu, sekitar periode Preneolitik. Unsur kapak perimbas dari teknologi Paleolitik masih ditemukan dalam 
Potensi Situs Gua Hunian Prasejarah di Kawasan Karst

Pegunungan Meratus, Kalimantan Selatan 1-11

lapisan Preneolitik ini, serta unsur gerabah yang ditafsirkan dari masa perundagian, sedangkan unsur logam/artefak logam tidak ditemukan (Widianto dan Handini 2003, 5). Di wilayah Gunung Batu Buli juga terdapat sebuah gua, yaitu Gua Tengkorak. Di Gua Tengkorak ini ditemukan rangka manusia yang dikuburkan langsung tanpa wadah dengan posisi terlipat miring. Identifikasi rangka tersebut merupakan manusia dari ras Australomelanesid, dengan jenis kelamin perempuan, usia antara 40-60 tahun. Temuan rangka tersebut merupakan temuan satusatunya di kawasan Batu Buli bahkan di Kalimantan (Widianto dan Handini 2003, 60). Migrasi ras Australomelanesid diperkirakan berawal dari 10.000 tahun yang lalu dari daratan Asia Tenggara ke arah selatan dan daerah bagian barat Nusantara. Berbagai temuan sisa rangka telah menjelaskan hal tersebut, selain bukti-bukti budaya yang tersebar di Vietnam, Thailand serta di Indonesia bagian barat dan selatan. Data terakhir yang ditemukan di Song Keplek dan Gua Braholo di kawasan Gunung Sewu, Jawa Tengah menunjukkan okupasi jenis ras ini pada kurun waktu antara 6.000 - 10.000 tahun yang lalu (Handini dan Widianto 1998; 1999). Pada satu titik, pergerakan ini bercabang menuju ke utara, yakni Kalimantan, melalui kawasan Pegunungan Meratus. Perkembangan manusia prasejarah di wilayah sekitar Pegunungan Meratus di Kalimantan Selatan memang sudah cukup banyak bukti-buktinya. Bukti tersebut berasal dari masa Paleolitik dengan ditemukan beberapa alat batu kapak perimbas penetak dan kapak bahu di sepanjang aliran Sungai Riam Kanan (Heekeren 1951). Penelusuran wilayah aliran Sungai Riam Kanan yang dilakukan Balai Arkeologi Banjarmasin selanjutnya juga menemukan beberapa peralatan batu Paleolitik di hulu Sungai Riam Kanan. Jika peralatan batu ini inheren bukan tradisi, maka dapat diperkirakan bahwa perkembangan manusia prasejarah di Kalimantan Selatan memang melewati jalur kawasan karst yang ada di sekitar Sungai Riam Kanan.

Sementara itu, di bagian tengah Pegunungan Meratus yang ada di wilayah Kabupaten Hulu Sungai Tengah, Hulu Sungai Selatan dan Tapin, juga menyimpan potensi gua hunian prasejarah yang cukup bagus. Hasil penelitian tahun 2005 menunjukkan bahwa di wilayah Kabupaten Hulu Sungai Tengah dan Hulu Sungai Selatan juga ditemukan beberapa gua yang mempunyai indikasi hunian manusia prasejarah. Sisa-sisa makanan serta artefak lainnya seperti perhiasan kerang dan temuan gigi manusia menjadi bukti bahwa gua-gua ini pernah ditempati (Wasita dkk 2005). Lereng-lereng pada perbukitan kapur yang ada di kedua kabupaten tersebut menunjukkan kemiringan yang landai, terjal, dan bahkan di beberapa tempat menunjukkan adanya lereng tegak lurus. Daerah dataran di kaki bukit umumnya merupakan daerah persawahan. Sejauh hasil penelitian yang didapatkan, gua-gua di Kabupaten Hulu Sungai Tengah tidak potensial untuk hunian, karena bentuk gua yang tidak memberi kenyamanan untuk tinggal. Ini terlihat dari lantai gua yang cenderung tidak datar. Hanya ada satu gua yang lantainya datar, dan di dalam gua tersebut tidak ditemukan adanya indikasi temuan artefaktual maupun ekofak yang pernah dimanfaatkan oleh manusia. Masih banyak kawasan karst lain di Kabupaten Hulu Sungai Tengah yang belum dikunjungi dan diteliti. 
Gua-gua yang ada di Telaga Langsat, Kabupaten Hulu Sungai Selatan, beberapa di antaranya secara bentuk dan temuan memberi kemungkinan adanya hunian gua. Gua Pendalaman 1 misalnya, ada temuan yang cukup banyak yang terkait dengan aktivitas kehidupan. Dari hasil pengamatan permukaan dan hasil penggalian test pit didapatkan adanya temuan yang berupa fragmen tembikar, fragmen tatal batu, fragmen tulang manusia, fragmen tulang hewan, kerang, dan arang. Fragmen tembikar memberi petunjuk adanya wadah yang digunakan oleh manusia yang menghuni gua pada saat mereka memasak dan menyiapkan makanan. Sayang, bahwa bentuk tembikar tidak dapat direkonstruksi dari pecahanpecahan yang ditemukan. Hal ini dikarenakan fragmen tembikar berupa bagian dari badan dan hanya sedikit yang berasal dari tepian. Pada umumnya berupa fragmen gerabah berukuran kecil. Berdasarkan fragmen tepian yang berhasil didapatkan, dihasilkan gambar rekonstruksi berupa periuk. Ini menunjukkan bahwa tembikar tersebut mempunyai peranan yang sangat besar dalam kaitannya dengan pengolahan dan penyediaan makanan. Dari segi konteks, ini menjadi sangat signifikan jika dikaitkan dengan adanya temuan arang. Temuan tersebut memberi indikasi adanya proses memasak makanan dengan menggunakan wadah periuk. Satu lagi temuan yang dapat memberi indikasi yang kuat dalam kaitannya dengan penyediaan makanan adalah adanya temuan tulang binatang. Dengan demikian, ketiganya saling mendukung adanya fungsi gua sebagai hunian manusia. Sedangkan temuan tulang manusia menunjukkan bahwa di gua tersebut memang terdapat manusia yang menghuni.
Ini dibuktikan oleh adanya fragmen tulang manusia yang meninggal dan terkubur di gua tersebut (Wasita dkk 2005).

Sementara itu, di bagian tenggara Pegunungan Meratus yang berada di wilayah Kabupaten Tanah Bumbu dan Kotabaru, memperlihatkan sumber daya kawasan karst yang cukup luas. Kawasan karst yang ada di wilayah Kabupaten Tanah Bumbu, terutama di Kecamatan Mantewe diketahui menyimpan situs gua hunian prasejarah yang potensial. Contoh gua yang sudah diteliti dan menunjukkan indikasi pemukiman adalah Gua Sugung, Gua Payung (Batu Tanjak), dan Liang Bangkai. Ketiga situs gua dan ceruk tersebut sedang dalam penelitian Balai Arkeologi Banjarmasin sejak tahun 2006 (Sugiyanto 2008; 2010). Selain ketiga situs tersebut, kawasan karst di Kecamatan Mantewe mempunyai gua dan ceruk payung lain yang belum sempat disurvei. Ada harapan bahwa di kawasan karst inilah merupakan lokasi perkembangan budaya prasejarah yang pernah ada pada masa lalu.

\section{Potensi Hunian Kawasan Karst di Pegunungan Meratus}

Perubahan bentuk daratan Kepulauan Indonesia di Kala Plestosen antara lain disebabkan oleh gerakan pengangkatan, kegiatan gunung api, dan turunnya permukaan air laut. Susut laut ini terjadi beberapa kali selama masa glasial. Bagian terbesar air di dunia membeku, sehingga jumlah air laut mengalami pengurangan yang sangat signifikan. Akibatnya permukaan air laut turun sampai 100 meter di bawah permukaan semula. Peristiwa ini mengakibatkan laut-laut dangkal seperti Laut Jawa dan Selat Karimata berubah menjadi daratan, dan muncullah dataran luas baru yang menghubungkan 
Potensi Situs Gua Hunian Prasejarah di Kawasan Karst

Pegunungan Meratus, Kalimantan Selatan 1-11

Sumatera, Jawa, dan Kalimantan dengan Benua Asia. Dataran baru ini disebut dengan Paparan Sunda, yang kemudian merupakan "jembatan" hubungan untuk perpindahan manusia dan binatang di daratan Asia Tenggara dan Kepulauan Indonesia. Sementara di bagian timur Indonesia pada saat yang sama juga terbentuk Paparan Sahul, yang menghubungkan Pulau Irian dengan Benua Australia (Heekeren 1972, 7).

Berdasarkan penelitian orohydrografi dan zoogeografi yang dilakukan oleh G.A.F Molengraaf dan M. Weber, dapat diketahui bentuk topografi Paparan Sunda berikut sungai-sungainya. Salah satu yang terlihat adalah Sungai Kahayan, Barito, dan Sampit di Kalimantan Selatan terlihat bergabung dengan sungai-sungai dari Lampung dan sungaisungai di Jawa bagian utara, dan bermuara bersama-sama di sebelah utara Pulau Bali (Marks, tt, 67). Daerah endapan sungai purba yang terbentuk Kala Plestosen ini mempunyai arti yang sangat penting bagi penelitian kehidupan manusia dan lingkungan pada masa lalu. Pada undak-undak sungai inilah biasanya terendapkan sisa-sisa kehidupan manusia masa lalu. Penelitian geologis, paleontologis, dan arkeologis atas beberapa undak sungai di Punung (Pacitan), Ngandong (Blora), dan Cabbenge (Sulawesi Selatan) membuktikan bahwa sungai-sungai di atas mengendapkan bermacam-macam batuan, perkakas manusia, fosil manusia, fosil hewan, dan fosil tumbuhan. Fosil manusia masih terbatas di undak-undak Sungai Bengawan Solo di Ngandong.

Temuan kapak perimbas yang pertama di Kalimantan didapatkan di dasar Sungai Riam Kanan di Awangbangkal, Kecamatan Karangintan. Sungai Riam Kanan terletak di sebelah barat Pegunungan Meratus. Daerah aliran sungai Riam Kanan ini melintasi susunan lapisan-lapisan yang berasal dari Pratersier dan Tersier (Heekeren 1951, 510512). Tampaknya, daerah aliran sungai memang menjadi lokasi yang digemari oleh manusia prasejarah. Hal ini terkait dengan keperluan akan air bersih untuk tetap bertahan hidup. Selain itu, daerah aliran sungai juga menyediakan sumber bahan makanan yang sangat melimpah. Banyak jenis hewan besar kecil yang sering mendatangi daerah aliran sungai untuk minum. Selain binatang-binatang besar yang biasa diburu, sungai juga menyediakan bahan subsistensi lain, seperti ikan, udang, dan kura-kura. Di sekitar daerah aliran sungai seperti inilah, manusia prasejarah membuat pangkalan yang cukup dilindungi oleh tedeng dahan-dahan pohon dan daun-daunan. Hewan yang menjadi buruan antara lain kuda nil, badak, kerbau, banteng, rusa, monyet, dan lain sebagainya. Manusia akan terus bergerak di sepanjang aliran sungai mengikuti pergerakan binatang buruan dan tinggal di tempat yang dipandang aman.

Oleh karena itu, tidaklah aneh jika pada aliran sungai-sungai seperti ini banyak ditemukan peralatan batu dari masa lalu. Oleh karena bahan batuan juga didapatkan di sungai, sehingga sangatlah praktis jika mereka membuat alat batu juga di sekitar sungai. Proses pembuatan alat langsung di lokasi sumber bahan batuan merupakan satu pilihan cerdas pada masa itu. Batuan-batuan yang masif dan cukup berat memang agak menyulitkan jika dibawa terus bergerak sampai ke gua-gua hunian. Ada beberapa pecahan yang mungkin agak kecil dan ringan yang dibawa sampai ke lokasi hunian untuk pengerjaan lanjutan. Proses pengerjaan alat batu inilah yang kemudian sampai ke tangan kita, sebagai sisa-sisa pengerjaan alat yang berada di lapisan tanah di dalam gua atau 
ceruk hunian manusia prasejarah. Pengenalan secara tidak sengaja terhadap gua-gua dan ceruk payung yang ada di suatu kawasan karst menimbulkan perubahan secara signifikan dalam tahapan kehidupan manusia. Seperti itulah, kawasan karst di sekitar aliran sungai di Pegunungan Meratus, memunculkan inovasi baru, yaitu pemanfaatan gua dan ceruk yang ada pada kawasan karst tersebut. Gua dan ceruk payung digunakan sebagai tempat tinggal sementara yang akan ditinggalkan jika dirasa tidak memungkinkan untuk meneruskan kehidupan di tempat itu. Pemanfaatan gua dan ceruk inilah yang menjadi awal kehidupan menetap dengan mulai menjinakkan binatang dan bercocok tanam sederhana. Masa penghunian gua dan ceruk inilah yang kemudian berkembang pesat di bagian utara Pegunungan Meratus, dengan contoh Gua Babi dan Gua Tengkorak di Kabupaten Tabalong. Sementara di bagian tengah Pegunungan Meratus, juga nampak indikasi kehidupan prasejarah pada kawasan karst di Telaga Langsat, Kabupaten Hulu Sungai Selatan, seperti: Gua Pendalaman dan Gua Janggarawi. Di bagian selatan Pegunungan Meratus, di bagian barat diwakili oleh Situs Awangbangkal, Kecamatan Karangintan, Kabupaten Banjar, dan di bagian timur diwakili oleh gua-gua yang ada di Kecamatan Mantewe, Kabupaten Tanah Bumbu.

Yang menjadi dasar adalah budaya prasejarah yang berkembang di Gua Babi dan Gua Tengkorak, sekitar 6.000 tahun lalu. Sampai sekarang memang belum dapat dijelaskan keberadaan manusia prasejarah di lokasi ini berasal dari mana. Akan tetapi, berdasarkan data temuan kapak perimbas yang ada di Sungai Riam Kanan, Kabupaten Banjar, dapat diperkirakan daerah Riam Kanan (Awangbangkal) inilah situs Paleolitik di
Kalimantan Selatan. Dari Awangbangkal, kemungkinan besar manusia prasejarah bergerak ke arah utara dan timur. Pergerakan ke arah utara melalui kawasan karst di Kabupaten Banjar, Tapin, Hulu Sungai Tengah, sampai Tabalong. Sementara yang ke arah timur melalui kawasan karst di Kabupaten Banjar, Tanah Bumbu, dan Kotabaru. Jika hipotesis ini benar, akan ditemukan situs gua dan ceruk hunian lain yang ada di kawasan karst di Pegunungan Meratus ini. Semakin banyak situs gua hunian ditemukan akan semakin terbuka cakrawala baru tentang kehidupan prasejarah di wilayah Kalimantan Selatan.

Potensi air bersih yang ada di sungai dan danau atau rawa-rawa yang ada di sekitar kawasan karst merupakan faktor pendukung yang penting dalam pemanfaatan gua dan ceruk sebagai tempat tinggal sementara dan tetap. Manusia prasejarah yang awalnya hanya mendirikan pondokan sederhana di sepanjang daerah aliran sungai mulai nyaman dengan keberadaan gua atau ceruk payung, yang langsung menyediakan tempat berlindung dan istirahat yang baik. Di dalam gua dan ceruk itu, mereka lebih aman dari gangguan cuaca dan ancaman binatang buas. Oleh karena itu, pemilihan gua dan ceruk sebagai tempat tinggal selalu didasarkan pada faktor kedekatan dengan sumber air dan sumber bahan makanan lainnya. Penemuan situs hunian prasejarah selama ini membuktikan bahwa masyarakat prasejarah di sekitar Pegunungan Meratus memang hanya memilih gua dan ceruk yang dekat dengan sumber air, seperti Gua Babi, Gua Tengkorak (Tabalong), Gua Sugung, Gua Payung, dan Liang Bangkai (Tanah Bumbu). Tidak semua gua dan ceruk yang layak huni dipilih sebagai tempat tinggal, padahal lingkungan karst setempat terdapat gua dan 
ceruk yang cukup banyak. Contohnya di Gunung Batubuli (Tabalong), selain Gua Babi dan Gua Tengkorak, paling tidak ada empat gua lain yang layak huni. Tetapi kenyataannya keempat gua tersebut tidak pernah dimanfaatkan sebagai tempat tinggal, karena memang tidak ada temuan sisa-sisa kehidupan manusia di dalamnya.

Semakin banyak gua dan ceruk hunian prasejarah di kawasan karst di Pegunungan Meratus yang terungkap, akan semakin menambah wawasan dan pengetahuan kita tentang kehidupan serta kebudayaan manusia pada masa lalu. Potensi sejarah budaya ini sangat penting dan dapat dikembangkan menjadi salah satu daya tarik objek pariwisata budaya di wilayah Kalimantan Selatan, sesuai dengan keinginan para wisatawan, yaitu:ingin melihat (1) sesuatu yang berbeda; (2) sesuatu yang baru; (3) sesuatu yang spektakuler; dan (4) sesuatu untuk difoto. Ingin bertamasya dengan nyaman dengan sedikit usaha. Ingin menggabungkan antara petualangan dengan waktu senggang Objek wisata yang paling berhasil adalah objek wisata yang bisa mengkombinasikan sejumlah minat yang berbeda, seperti olahraga, satwa liar, flora, pemandangan yang indah, tempat bersejarah, pakaian atau adat istiadat setempat, dansa/ tarian, laut, danau, sungai, kolam renang, air terjun, dan lain-lain yang memiliki nilai rekreasi.

\section{Kesimpulan}

Berdasarkan uraian di atas, Pegunungan Meratus merupakan lokasi yang sangat penting bagi kehidupan manusia dari masa prasejarah sampai sekarang. Sekarang terlihat banyak kelompok masyarakat Dayak yang berdiam di sekitar Pegunungan Meratus, dengan mengembangkan pola pertanian sederhana, slash and burn. Pemilihan lokasi pemukiman di sekitar Pegunungan Meratus ini sudah diawali oleh manusia prasejarah pada masa lalu. Paling tidak sekitar 6.000 tahun lalu, terdapat sekelompok manusia yang mengembangkan budaya prasejarah di Gua Babi dan Gua Tengkorak dengan mata pencaharian berburu dan mengumpulkan makanan.

Berdasarkan temuan kapak perimbas di Awangbangkal, diperkirakan budaya prasejarah di Kalimantan Selatan berawal dari percabangan migrasi manusia dari Jawa, yang kemudian berkembang ke arah utara Pegunungan Meratus sampai di Gua Babi dan Gua Tengkorak. Sementara yang bergerak ke arah timur sampai di situs gua-gua hunian yang ada di Kabupaten Tanah Bumbu dan Kotabaru.

Potensi air bersih dan sumber bahan makanan yang disediakan oleh hutan-hutan kecil di sekitar kawasan karst di Pegunungan Meratus membuat masyarakat prasejarah memilih dan memanfaatkan gua-gua dan ceruk payung yang ada sebagai tempat tinggal, baik sementara maupun tetap. Pemilihan ini terkait dengan kondisi lahan Kalimantan Selatan yang terdiri dari dataran rendah dan dataran tinggi. Dataran rendahnya banyak didominasi oleh rawa-rawa gambut yang mungkin sangat menyulitkan bagi masyarakat prasejarah. Oleh karena itu, mereka mengarahkan pergerakan kehidupan ke dataran tinggi terutama pada kawasankawasan karst di sekitar Pegunungan Meratus, melalui sungai-sungai besar dan anak sungainya. Pergerakan yang lebih mudah, sumber bahan makanan yang lebih banyak serta ketersediaan air bersih merupakan tiga faktor utama yang mendukung pemilihan dan pemanfaatan gua atau ceruk payung sebagai tempat tinggal masyarakat prasejarah di wilayah Kalimantan Selatan pada masa lalu. 


\section{Referensi}

Bemmelen, R. W van. 1949. The geology of Indonesia Vol. I. The Hague: Martinus Nijhoff.

De Terra, H. 1943. Pleistocene geology early man in Jawa. Trans of the Americ. Phill. Soc XXXIl: 437-466.

Hekeeren, H. R. van. 1951. Korte Mededelingen: Het Hoabinhian in Zuid Borneo. Tijds, v. Indische Bat. Genoots: 508-512.

1972. The stone age of Indonesia. The Haque: Martinus Bijhoff.

Koenigswald, G. H. R. von. 1934. Zur stratigraphie des javanischen Pleistozän. Die Ingenieur in Nederlandsch-Indie I (11): 185-201. . 1935. Paleobiological and sedimentological implications to fossil concentration. Nature 318: 457460.

Molengraaff, G. A. F. dan M. Weber. 1921. The relation between Pleistocene Glacial period and the origin of the Sunda Sea, and its influence on the distribution of coral reefs and on the land and fresh water fauna, Proc. Kon. Ned. Akad. Van Wetenscsch 23: 395439.

Nasrudin, Jatmiko, dan Bambang Sugiyanto 2004. Eksploitasi situs-situs gua hunian prasejarah di Pegunungan Marang, Kabupaten Kutai Timur, Kalimantan Timur. Laporan Penelitian Arkeologi . Kerjasama antara Deputi Urusan Arkeologi
Nasional dengan CNRS-France. Jakarta: Deputi Urusan Arkeologi Nasional.

MacKinnon, Kathy, Gusti Hatta, Hakiman Halim, dan Arthur Mangalik, 1996. The ecology of Kalimantan. Periplus Edition.

Marks, P. tt. Geologi sejarah jilid IV. Bandung: Balai pendidikan Guru.

Semah, A. M. 1996. Pleistocene and holocene enviromental changes, Indonesian heritage: ancient history. Jakarta : Buku Antar Bangsa for Grolier Internasional Inc.

Soejono, R. P. 1993. Sejarah nasional Indonesia jilid I. Jakarta: Balai Pustaka.

Sugiyanto, Bambang. 2008. Hunian gua prasejarah di Kecamatan Mantewe, Kalimantan Selatan. Berita Penelitian Arkeologi 3 (1): 1 - 23. 2010. Penelitian prasejarah Liang Bangkai, Kecamatan Mantewe,Kabupaten Tanah Bumbu, Kalimantan Selatan (Tahap III). Laporan Penelitian Arkeologi. Banjarbaru: Balai Arkeologi Banjarmasin, belum terbit. 2012. Penelitian prasejarah Liang Bangkai, Kecamatan Mantewe, Kabupaten Tanah Bumbu, Kalimantan Selatan (tahap IV). Laporan Penelitian Arkeologi. Banjarbaru: Balai Arkeologi Banjarmasin, belum terbit. 
Potensi Situs Gua Hunian Prasejarah di Kawasan Karst

Pegunungan Meratus, Kalimantan Selatan 1-11

Wasita, dkk. 2005. Penelitian eksploratif guagua prasejarah di Kabupaten Hulu Sungai Selatan dan Hulu Sungai Tengah, Kalimantan Selatan, Laporan Penelitian Arkeologi. Banjarbaru; Balai Arkeologi Banjarmasin, belum diterbitkan.

Widianto, Harry, Truman Simanjuntak, dan Budianto Toha. 1997. Ekskavasi situs
Gua Babi, Kabupaten Tabalong, Kalimantan Selatan. Berita Penelitian Arkeologi 1.

Widianto, Harry dan Retno Handini. 2003. Karakter budaya di Situs Gua Babi: mekanisme hunian gua prasejarah pasca-plestosen. Berita Penelitian Arkeologi 13. 